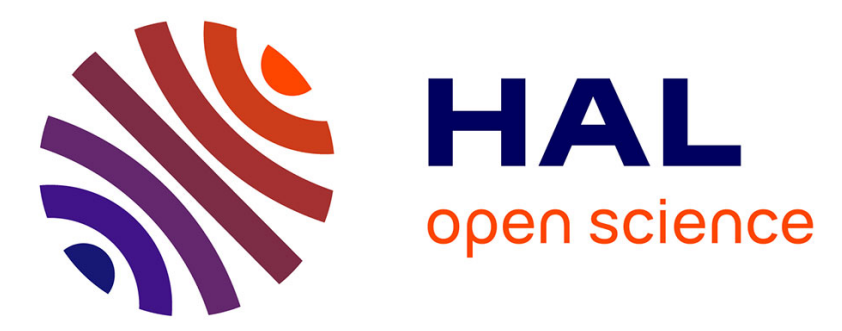

\title{
Effects of competition between alfalfa (Medicago sativa L.) hybrid and inbred plants on their seed and forage yield (1)
}

Fabio Veronesi, Francesco Damiani, Stefania Grando, Franco Lorenzetti

\section{- To cite this version:}

Fabio Veronesi, Francesco Damiani, Stefania Grando, Franco Lorenzetti. Effects of competition between alfalfa (Medicago sativa L.) hybrid and inbred plants on their seed and forage yield (1). Agronomie, 1985, 5 (1), pp.1-6. hal-00884726

\section{HAL Id: hal-00884726 https://hal.science/hal-00884726}

Submitted on 1 Jan 1985

HAL is a multi-disciplinary open access archive for the deposit and dissemination of scientific research documents, whether they are published or not. The documents may come from teaching and research institutions in France or abroad, or from public or private research centers.
L'archive ouverte pluridisciplinaire HAL, est destinée au dépôt et à la diffusion de documents scientifiques de niveau recherche, publiés ou non, émanant des établissements d'enseignement et de recherche français ou étrangers, des laboratoires publics ou privés. 


\title{
Effects of competition between alfalfa (Medi- cago sativa L.) hybrid and inbred plants on their seed and forage yield (1)
}

\author{
Fabio VERONESI, Francesco DAMIANI $\left({ }^{*}\right)$, Stefania GRANDO \& Franco LORENZETTI \\ Plant Breeding Institute of University of Perugia, I 06100 Perugia, Italy \\ (*) Forage Plant Breeding Centre of National Research Council of Italy, I 06100 Perugia, Italy
}

SUMMARY

A study was conducted at Perugia (Italy) in 1981/1982 to evaluate the importance of competition in alfalfa (Medicago sativa L.) and to investigate the consequence of different percentages of inbred seeds on seed and forage yield. Three mixtures having ratios of inbred seed to hybrid seed $\left(S_{1} / F_{1}\right)$ of $1 / 9,1 / 2.33,1 / 1$ were sown, seed by seed, in micro-plots $(50 \times 30 \mathrm{~cm})$ at a seeding rate of $1600 \mathrm{seeds} / \mathrm{m}^{2}$.

In 1981 data were collected on : establishment ; green matter yield per plant and dry matter yield $/ \mathrm{m}^{2}$ at $1 \mathrm{st}, 2$ nd and 3rd cut ; number of plants alive in the fall. In 1982 data were collected on : number of plants alive in the spring ; green matter yield per plant and dry matter yield $/ \mathrm{m}^{2}$ at 1 st and 3rd cut ; seed yield per plant at 2 nd cut ; height per plant at 1 st cut.

The results can be summarized as follows : 1 ) forage yield of $S_{1}$ was much lower than that of $F_{1}$ plants in each of the 3 mixtures ; 2) since no differences were observed in dry matter yield $/ \mathrm{m}^{2}$ among mixtures, differences in $S_{1}$ seed percentage would not seem important to productivity of alfalfa ; 3) selective elimination of $S_{1}$ plants was present and particularly strong during the seeding year. One year after seeding only few $S_{1}$ plants survived ; 4 ) only $2 \%$ of the seed produced in the 2 nd year came from $S_{1}$ plants.

Effets de la compétition entre plantes de luzerne issues d'hybridation et d'autofécondation sur la production des semences et du fourrage.

En 1981-82, une recherche implantée à Pérouse (Italie) a eu pour but l'évaluation des conséquences que peuvent avoir différents pourcentages de semences obtenues par autofécondation sur la production de semences et de fourrage chez la luzerne (Medicago sativa $\mathbf{L}$.). Trois mélanges, ayant une proportion entre semences obtenues par autofécondation et semences hybrides $\left(\mathrm{S}_{1} / \mathrm{F}_{1}\right)$ respectivement de $1 / 9,1 / 2,33,1 / 1$, ont été semés, graine par graine, sur des microparcelles (de $50 \times 30 \mathrm{~cm}$ ) ayant une densité de 1600 graines par $\mathrm{m}^{2}$.

En 1981 ont été relevées les données relatives à l'implantation, à la production de matière verte par plante et de matière sèche par $\mathrm{m}^{2}$ à la $1^{\mathrm{re}}, 2^{\mathrm{e}}$ et $3^{\mathrm{e}}$ coupe, au nombre de plantes vivantes en automne. En 1982 ont été relevées les données relatives au nombre de plantes vivantes au printemps, à la production de substance verte par plante et de substance sèche par $\mathrm{m}^{2}$ à la $1^{\text {re }}$ et $3^{\mathrm{e}}$ coupe, à la hauteur des plantes à la $1^{\text {re }}$ coupe, à la production de semences par plante à la $2^{e}$ coupe.

Les résultats peuvent être ainsi synthétisés : 1) dans les 3 mélanges, les plantes $S_{1}$ ont donné une production de fourrage beaucoup plus faible que celle des plantes $F_{1} ; 2$ ) étant donné qu'il n'y a pas de différences significatives entre les mélanges pour la production de matière sèche par $\mathrm{m}^{2}$, de grandes différences dans la proportion de semences issues l'autofécondation dans les lots de départ ne semblent pas influencer de façon significative la production fourragère de la luzerne ; 3) il y a eu une sélection des plantes $S_{1}$ particulièrement forte pendant l'année d'implantation. Après une année, le nombre des plantes $S_{1}$ survivantes a été très limité ; 4) les plantes $S_{1}$ ont contribué seulement dans la mesure de $2 \%$ à la production de semences de l'année 1982.

\section{INTRODUCTION}

Genetic improvement of perennial forage species, such as alfalfa (Medicago sativa L.) is usually carried out under non-competitive conditions which are very

(1) Research supported by the National Research Council of Italy, Centro di Studio per il Miglioramento Genetico delle Piante Foraggere c/o Istituto di Miglioramento Genetico Vegetale, Università degli Studi di Perugia, 06100 Perugia (Italy). different from those of commercial production (SCHAAF, 1976 ; LORENZETTI \& PORCEDDU, 1977). The value of data collected on spaced plants depends on the significance of the correlation between the behaviour of the plants in breeding environment and in production trials. In alfalfa, selection based on plants grown at wide spacing is quite effective for highly heritable traits, such as disease resistance and maturity (CHRISTIE \& KEOGHAN, 1979), but is not 
effective for herbage yield and other important quantitative characters distinctly affected by competition where strong genotype per density interaction is present (TYSDAL \& KIESSELBACH, 1944 ; PEARSON \& ELling, 1961 ; PANELla \& LORENZETTI, 1968 ; BUSBICE et al., 1972). Therefore, as already stressed by ROTILI (1979), selection for alfalfa forage yield should be carried out under dense stand conditions. In this context, the study of competition between hybrid and inbred plants holds a high interest in understanding both the structure of the populations to be improved and the kind of varieties (hybrids or synthetics) to be produced. A strong selective pressure is present in alfalfa stands and the number of plants surviving the first year after seeding is generally in the range of 20-30\% of the seed sown (VIVENZA, 1914 ; HAUSSMAN, 1955 ; BROWN et al., 1960 ; PANELla, 1960 ; DeMARLY et al., 1964 ; TESAR \& JACOBS, 1972) ; this percentage further decreases in subsequent years to reach values around $10 \%$ of seed sown at the end of the third year (VERONESI et al., 1982).

A natural alfalfa population can be assumed as a mixture of inbred and hybrid plants, the percentage of selfing (largely dependent on environmental conditions) falling between $15 \%$ (LESINS, 1961) and more than $40 \%$ (VERONESI \& LORENZETTI, 1982).

With the aim of evaluating the consequences of different percentages of inbred and hybrid plants on forage and seed yield in alfalfa, a study started at Perugia (Italy) in 1981 in which three seed mixtures having different ratios of inbred and hybrid seed were sown and evaluated under dense stand conditions.

\section{MATERIALS AND METHODS}

During the two year period 1981-1982 an alfalfa trial was conducted at Perugia (Italy) using three seed mixtures having ratios of inbred seed to hybrid seed $\left(\mathrm{S}_{1} / \mathrm{F}_{1}\right)$ of $1 / 9,1 / 2.33$ and $1 / 1$. Seeds were sown in micro-plots $(50 \times 30 \mathrm{~cm})$ at a seeding rate of 1600 seeds $/ \mathrm{m}^{2}(32 \mathrm{~kg} / \mathrm{ha})$. This seed density is normally used in Italian alfalfa stands. The three mixtures will be referred as mixture A $\left(10 \% \mathrm{~S}_{1}\right)$, B $\left(30 \% S_{1}\right)$ and $C\left(\begin{array}{lll}50 & S_{1}\end{array}\right)$. The $S_{1}$ and $F_{1}$ seeds were produced from 30 highly vigorous plants chosen in a three-year old stand of the Italian ecotype "S. Apollinare" and space transplanted. The experiment was based on the hypothesis that in a three-year old stand only vigorous plants derived from crossing should be present (KEHR, 1976; LORENZETTI, 1978). Self-pollination was obtained by manipulating bagged racemes while cross-pollination was obtained by tripping non-emasculated flowers of each one of the 30 plants with folded papers on which a large amount of pollen random collected from the other plants was present. In this way, self-fertilization is reduced to a minimum (BONCIARELLI, 1960). On the whole 100 flowers per plant were selfed and 100 were crossed. The $F_{1}$ initial seed lot was constructed bulking equal numbers of seed from each maternal parent ; the $S_{1}$ initial seed lot was arranged the same way.

The seeds were scarified and each seed was sown 2.5 $\mathrm{cm}$ deep in the center of a square space $(2.5 \times 2.5 \mathrm{~cm})$ defined by the mesh of a plastic fence which was placed on each micro-plot surface and held in place with $30 \mathrm{~cm}$ nails. $F_{1}$ and $S_{1}$ seeds were randomly sown in each micro-plot, which had 240 seeds arranged in $20 \mathrm{~cm}$ rows with 12 seeds per row. Utilizing 2 rows around the perimeter as border it was possible to sow 16 rows of 8 seeds of experimental materials for each micro-plot (1 536 seeds in total). A complete randomized block design with four replications was employed. In 1981 data were collected on :

- establishment (number of plants alive 30 days after seeding) ;

- green matter yield ( $\mathrm{g} /$ plant) and dry matter yield $\left(\mathrm{g} / \mathrm{m}^{2}\right)$ at 1 st (June 15), 2nd (July 21) and 3rd cut (August 31) ;

- number of plants alive in the fall (October 30).

In 1982 data were collected on :

- number of plants alive in the spring (March 15) ;

- green matter yield ( $\mathrm{g} /$ plant) and dry matter yield $\left(\mathrm{g} / \mathrm{m}^{2}\right)$ at 1 st (June 2) and 3rd cut (October 13) ;

- height per plant $(\mathrm{cm})$ at 1 st cut (June 2) ;

- seed yield ( $\mathrm{g} /$ plant and $\mathrm{g} / \mathrm{m}^{2}$ ) at the 2 nd cut (August 17).

Green matter yield per plant and height data were transformed before analysis using the log transformation due to the skewness of the original data. Arcsin transformation was used on survival percentage data. Data are presented in actual units.

\section{RESULTS AND DISCUSSION}

Means of annual green matter yield per plant and dry matter yield per $\mathrm{m}^{2}$ in 1981 and 1982 are reported in table 1. In 1981, $S_{1}$ plants yielded $47 \%$ less than $F_{1}$ in mixture A (1.18vs $2.23 \mathrm{~g} / \mathrm{plant}), 65 \%$ less in B $(1.03 \mathrm{vs} 2.98 \mathrm{~g} / \mathrm{plant})$ and $60 \%$ less in $\mathrm{C}(1.31 \mathrm{vs}$ $3.25 \mathrm{~g} /$ plant) ; in 1982, $\mathrm{S}_{1}$ plants yielded $56 \%$ less in mixture A (2.13 vs $4.92 \mathrm{~g} /$ plant), $65 \%$ less in B $(2.23 v s 6.51 \mathrm{~g} / \mathrm{plant})$ and $72 \%$ less in C (2.21 vs $7.91 \mathrm{~g} /$ plant). The results indicate a strong inbreeding effect which tends to increase over time and is higher than that normally shown in spaced plant trials, where $S_{1}$ plants produce approximately $30 \%$ less than $F_{1}$ plants (PANELLA \& LORENZETTI, 1966 ; LORENZETTI $\&$ PoRCEDDU, 1968). Both in the 1st and in the 2nd year, different $S_{1}$ percentages did not significantly affect average green matter yield per plant or dry matter yield per $\mathrm{m}^{2}$ of the three mixtures (table 1).

With respect to classes of progeny, $S_{1}$ plants never showed significant average green matter yield differences among mixtures. On the contrary, $F_{1}$ plants in mixtures $\mathrm{A}, \mathrm{B}$ and $\mathrm{C}$ were all significantly different for this character in $1982 . F_{1}$ plants showed the lowest mean yield per plant in mixture A $(2.23 \mathrm{~g} /$ plant in 1981 and $4.92 \mathrm{~g} /$ plant in 1982), where the lowest number of $S_{1}$ plants was present, and the highest mean value in mixture C $(3.25 \mathrm{~g} /$ plant in 1981 and $7.91 \mathrm{~g} /$ plant in 1982), where the highest number of $S_{1}$ plants occurred (table 1).

Therefore, in accordance with CARNAHAN \& PADEN (1967) it seems that, in dense plantings containing genotypes varying in yield potential, the more vigorous plants will compensate for the lower 
TABLE 1

Annual green matter yield per plant and dry matter yield per $m^{2}$ in 1981 and 1982. Production annuelle de matière verte par plante et production de matière sèche par $m^{2}$ en 1981 et 1982.

\begin{tabular}{|c|c|c|c|c|c|c|c|c|}
\hline \multirow{3}{*}{ Mixtures } & \multicolumn{3}{|c|}{1981} & \multirow{3}{*}{$\begin{array}{c}\text { Dry matter } \\
\text { yield } \\
\left(\mathrm{g} / \mathrm{m}^{2}\right) \\
\text { mixture }\end{array}$} & \multicolumn{3}{|c|}{1982} & \multirow{3}{*}{$\begin{array}{c}\text { Dry matter } \\
\text { yield } \\
\left(\mathrm{g} / \mathrm{m}^{2}\right) \\
\text { mixture }\end{array}$} \\
\hline & \multicolumn{3}{|c|}{ green matter yield ( $\mathrm{g}$ /plant) } & & \multicolumn{3}{|c|}{ green matter yield ( $\mathrm{g} /$ plant) } & \\
\hline & $\mathrm{S}_{1}$ & $\mathrm{~F}_{1}$ & Mixture & & $\mathrm{S}_{1}$ & $\mathrm{~F}_{1}$ & Mixture & \\
\hline $\mathrm{A}\left(10 \% \mathrm{~S}_{1}\right)$ & $1.18 \mathrm{a}^{*}$ & $2.23 \mathrm{a}$ & $2.16 \mathrm{a}$ & $825 \mathrm{a}$ & $2.13 \mathrm{a}$ & $4.92 \mathrm{a}$ & $4.89 \mathrm{a}$ & $955 \mathrm{a}$ \\
\hline B $\left(30 \% \mathrm{~S}_{1}\right)$ & $1.03 \mathrm{a}$ & $2.98 \mathrm{a}$ & $2.57 \mathrm{a}$ & $905 \mathrm{a}$ & $2.23 \mathrm{a}$ & $6.51 \mathrm{~b}$ & $6.28 \mathrm{~b}$ & $1082 \mathrm{a}$ \\
\hline $\mathrm{C}\left(50 \% \mathrm{~S}_{1}\right)$ & $1.31 \mathrm{a}$ & $3.25 \mathrm{a}$ & $2.55 \mathrm{a}$ & $779 a$ & $2.21 \mathrm{a}$ & $7.91 \mathrm{c}$ & $6.89 \mathrm{~b}$ & $1049 \mathrm{a}$ \\
\hline
\end{tabular}

* Means within a column followed by the same letter not significantly different at $1 \%$ level.

yielding component of the population. Plant survivals percentages of seeds sown are reported in figure 1. Survival percentages for all plants in the three mixtures were never significantly different at any one observation time and varied between $55 \%$ (mixture C) and $64 \%$ (mixture $A$ ) at the end of the seeding year and between $37 \%$ (mixture A) and $27 \%$ (mixture C) at the end of the second year. These survival percentages are close enough to those reported by DEMARLY et al. (1964), TESAR \& JACKOBS (1972) and VERONESI et al. (1982) for alfalfa stands.

With respect to classes of progeny, percentages of $F_{1}$ plants alive in fall 1982 ranged between $41 \%$ (mixture A) and $45 \%$ (mixture C), whereas survival percentages of $S_{1}$ plants ranged between $1 \%$ (mixture B) and $10 \%$ (mixture C). The results of $\chi^{2}$ tests on number of plants alive at any one observation time versus number expected if there were no differences in survival between $S_{1}$ and $F_{1}$ plants in $A$, $\mathrm{B}$ and $\mathrm{C}$ mixtures are reported in table 2 . At the first observation time, we did not find evidence to reject the null hypothesis and this indicates that seedling elimination during establishment was not selective against $S_{1}$ genotypes. Selective elimination of $S_{1}$ plants started straight after, as soon as the struggle for light, water and nutrients began. In the process of competition plants with superior competitive ability obtain precedence and can attain more vigorous growth at the expense of weaker genotypes (YAMADA \& HORIUCHI, 1960). In general, the greater the frequency of weaker phenotypes in a population, the stronger is the action of intraspecific competition against them. Probably for this reason, the different survivals of $S_{1}$ and $F_{1}$ plants became significant at the second observation time in mixture $\mathrm{C}$ and at the fourth observation time in mixture $\mathrm{A}$ and $\mathrm{B}$. The $\chi^{2}$ values increased over time showing a $1 \%$ level of significance starting from the 3rd $(7 / 21 / 1981)$, the 4th $(8 / 31 / 1981)$ and the 6 th $(3 / 15 / 1982)$ observation times for mixtures $\mathrm{C}, \mathrm{B}$ and $\mathrm{A}$, respectively (table 2).

Numbers of plants alive and, in brackets, number of plants which produced seed at 1982 second cut (August 17) are reported in table 3. None of the $4 S_{1}$ plants alive in mixture $A$ produced seed. The percentages of $S_{1}$ plants which produced seed were between $0 \%$ (mixture A) and $2.7 \%$ (mixture $C$ ) of the seed sown. The same percentages relative to $F_{1}$
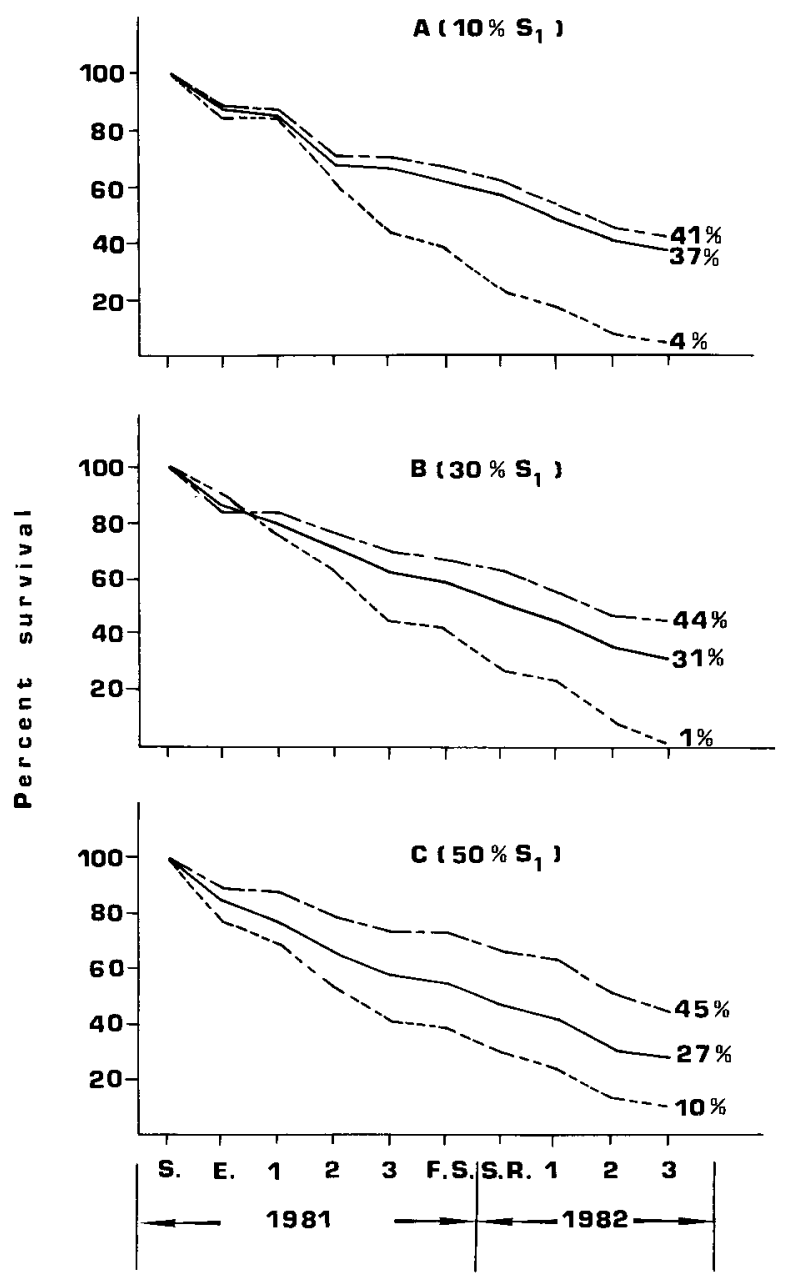

Figure 1

Plant survival percentages $(100 \%=$ number of seeds sown) in $\mathrm{A}$ $\left(10 \% S_{1}\right), B\left(30 \% S_{1}\right)$ and $C\left(50 \% S_{1}\right)$ mixtures. $(S .=$ seeding, $4 / 5 / 1981 ; E .=$ establishment, $5 / 5 / 1981 ; 1=1$ st cut, $6 / 15 / 1981 ; 2=2$ nd cut, $7 / 21 / 81 ; 3=3 r d$ cut, $8 / 13 / 1981 ; F . S$. $=$ fall survival, $10 / 31 / 1981 ;$ S.R. = spring regrowth, $3 / 15 / 1982 ;$ $1=1$ st cut, $6 / 2 / 1982 ; 2=2$ nd cut, $8 / 17 / 1982 ; 3=3$ rd cut, $10 / 13 / 1982$ ).

$F_{1}+S_{1} ;---F_{1} ;-\cdots-S_{1}$.

Pourcentage des plantes vivantes $(100 \%=$ nombre des semences semées) dans les mélanges $A\left(10 \% S_{1}\right), B\left(30 \% S_{1}\right)$ et $C(50 \%$ $\left.S_{1}\right) .(S .=$ ensemencement, $5 / 4 / 1981 ; E .=$ implantation, $5 / 5 / 1981 ; 1=I^{r e}$ coupe, $15 / 6 / 1981 ; 2=2^{e}$ coupe, $21 / 7 / 1981 ; 3$ $=3^{e}$ coupe, $13 / 8 / 1981 ; F . S .=$ chute de la survivance, $31 / 10 / 1981 ;$ S.R. $=$ repousse de printemps $; 15 / 3 / 1982 ; 1=1^{\text {re }}$ coupe, $2 / 6 / 1982 ; 2=2^{e}$ coupe, $17 / 8 / 1982 ; 3=3^{e}$ coupe, $13 / 10 / 1982)$. 
TABLE 2

Results of $\chi^{2}$ tests on number of plants alive in mixtures $A, B$ and $C$ at the following observation times : 5/5/1981 (establishment), 6/15/1981 (Ist cut), 7/21/1981 (2nd cut), 8/31/1981 (3rd cut), 10/30/1981 (fall survival), 3/15/1982 (spring regrowth), 6/2/1982 (1st cut), 8/17/1982 (2nd cut), 10/13/1982 (3rd cut). $H_{0}$ hypothesis : no differences in survival between $S_{1}$ and $F_{1}$ plants in $A, B$ and $C$.

Résultats des tests $\chi^{2}$ sur les plantes vivantes dans les mélanges $A, B$ et $C$ aux dates d'observation suivantes : 5/5/1981 (implantation), 15/6/1981 ( $1^{r e}$ coupe), 21/7/1981 (2e coupe), 31/8/1981 (3e coupe), 30/10/1981 (chute de la survivance), 15/3/1982 (repousse de printemps), 2/6/1982 (1 ${ }^{r e}$ coupe), 17/8/1982 (2 $2^{e}$ coupe), 13/10/1982 (3e coupe). Hypothèse $H_{0}:$ il $n^{\prime} y$ a aucune différence dans la survivance entre plantes $S_{l}$ et $F_{l}$ dans les mélanges $A, B, C$.

\begin{tabular}{|c|c|c|c|c|c|c|c|c|c|c|c|}
\hline & \multirow{3}{*}{ Mixtures } & \multirow{3}{*}{$\begin{array}{l}\text { Seeds } \\
\text { sown }\end{array}$} & \multicolumn{5}{|c|}{1981} & \multicolumn{4}{|c|}{1982} \\
\hline & & & $5 / 5$ & $6 / 15$ & $7 / 21$ & $8 / 31$ & $10 / 30$ & $3 / 15$ & $6 / 2$ & $8 / 17$ & $10 / 13$ \\
\hline & & & pp alive & pp alive & pp alive & pp alive & pp alive & pp alive & pp alive & pp alive & pp alive \\
\hline \multirow{3}{*}{$\mathrm{A}$} & $S_{1}(10 \%)$ & 52 & 44 & 43 & 32 & 23 & 20 & 12 & 9 & 4 & 2 \\
\hline & $F_{1}(90 \%)$ & 460 & 404 & 393 & 320 & 320 & 309 & 286 & 242 & 208 & 190 \\
\hline & $\chi^{2}$ & - & n.s. & n.s. & n.s. & $*$ & $*$ & $* * *$ & $* * *$ & $* * *$ & $* * *$ \\
\hline \multirow{3}{*}{ B } & $S_{1}(30 \%)$ & 152 & 134 & 113 & 93 & 67 & 61 & 39 & 33 & 12 & 2 \\
\hline & $F_{1}(70 \%)$ & 360 & 300 & 295 & 273 & 251 & 242 & 224 & 200 & 167 & 159 \\
\hline & $\chi^{2}$ & - & n.s. & n.s. & n.s. & $* * *$ & $* * *$ & $* * *$ & $* * *$ & $* * *$ & $* * *$ \\
\hline \multirow{3}{*}{ C } & $S_{1}(50 \%)$ & 256 & 196 & 175 & 137 & 105 & 95 & 74 & 58 & 31 & 25 \\
\hline & $F_{1}(50 \%)$ & 256 & 229 & 222 & 200 & 188 & 186 & 169 & 158 & 127 & 115 \\
\hline & $x^{\frac{1}{2}}$ & - & n.s. & $*$ & $* * *$ & $* * *$ & $* * *$ & $* * *$ & $* * *$ & $* * *$ & $* * *$ \\
\hline
\end{tabular}

n.s. $=$ not significant $;^{*}=$ significant at $5 \%$ level ${ }^{* * *}=$ significant at $1 \%$ level.

TABLE 3

Number of plants alive and, in brackets, number of plants which produced seed in 1982 second cut (August 17). Nombre de plantes vivantes et, entre parenthèses, nombre de plantes qui ont produit des semences à la $2^{e}$ coupe de l'année 1982 (17 Août).

\begin{tabular}{lccc}
\hline \hline \multirow{2}{*}{ Mixtures } & \multicolumn{3}{c}{ Number of plants alive } \\
\cline { 2 - 4 } & $\mathrm{S}_{1}$ & $\mathrm{~F}_{1}$ & Total \\
\hline A $\left(10 \% \mathrm{~S}_{1}\right)$ & $4(-)$ & $208(88)$ & $212(88)$ \\
$\mathrm{B}\left(30 \% \mathrm{~S}_{1}\right)$ & $12(4)$ & $167(89)$ & $179(93)$ \\
$\mathrm{C}\left(50 \% \mathrm{~S}_{1}\right)$ & $31(7)$ & $127(70)$ & $158(77)$ \\
\hline \hline
\end{tabular}

plants were between $27.3 \%$ (mixture C) and $19.1 \%$ (mixture A). Only $17 \%, 18 \%$ and $15 \%$ of the total seed sown in mixtures $\mathrm{A}, \mathrm{B}$ and $\mathrm{C}$ gave plants which, in turn, produced seed.

Means of seed yield per plant and per $\mathrm{m}^{2}$ are reported in table $4 . S_{1}$ plants yielded $0.18 \mathrm{~g} / \mathrm{plant}$ in mixture $\mathrm{B}$ and $0.15 \mathrm{~g}$ /plant in mixture $\mathrm{C} ; \mathrm{F}_{1}$ plants yielded $0.28 \mathrm{~g} /$ plant in mixture $\mathrm{A}, 0.38 \mathrm{~g} / \mathrm{plant}$ in mixture $B$ and $0.43 \mathrm{~g} /$ plant in mixture $C$. Also these results indicate a clear inbreeding effect ; $S_{1}$ plants yielded $53 \%$ less than $F_{1}$ in $B$ mixture and $65 \%$ less in $\mathrm{C} . \mathrm{S}_{1}$ plants produced no seeds in A mixture, $0.6 \%$ of the total seed yield in $B$ and $1 \%$ in $C$.

With respect to classes of progeny, $S_{1}$ plants did not express significant average seed yield differences between $B$ and $C$ mixtures but the average seed yield of $F_{1}$ plants in mixture $A(0.28 \mathrm{~g} / \mathrm{plant})$ was significantly lower than those of $B(0.38 \mathrm{~g} / \mathrm{plant})$ and C $(0.43 \mathrm{~g} /$ plant $)$ which did not differ from each other. The average seed yield per plant of the three mixtures was affected by the different $S_{1}$ percentages, and mixture A showed a value $(0.28 \mathrm{~g} /$ plant $)$ significantly lower than those of $\mathrm{B}(0.38 \mathrm{~g} / \mathrm{plant})$ and $\mathrm{C}$ $(0.40 \mathrm{~g} /$ plant $)$. On the contrary, different $S_{1}$ percentages in the initial seed lots did not seem to effect average seed yield per $\mathrm{m}^{2}$ of the three mixtures (tabl. 4).

TABLE 4

Seed yield per plant and per $m^{2}$ in 1982.

Production de semences par plante et par $\mathrm{m}^{2}$ en 1982.

\begin{tabular}{|c|c|c|c|c|c|c|}
\hline \multirow{3}{*}{ Mixtures } & \multicolumn{6}{|c|}{ Seed yield } \\
\hline & \multicolumn{3}{|c|}{$\mathrm{g} /$ plant } & \multicolumn{3}{|c|}{$\mathrm{g} / \mathrm{m}^{2}$} \\
\hline & $\mathrm{S}_{1}$ & $\mathrm{~F}_{1}$ & Mixture & $S_{1}$ & $\mathrm{~F}_{1}$ & Mixture \\
\hline$A\left(10 \% S_{1}\right)$ & - & $0.28 \mathrm{a}$ & $0.28 \mathrm{a}$ & - & $77 \mathrm{a}$ & $77.0 \mathrm{a}$ \\
\hline B $\left(30 \% S_{1}\right)$ & $0.18 \mathrm{a}^{*}$ & $0.38 \mathrm{~b}$ & $0.38 \mathrm{~b}$ & $0.7 \mathrm{a}$ & $106 \mathrm{a}$ & $106.7 \mathrm{a}$ \\
\hline$C\left(50 \% S_{1}\right)$ & $0.15 \mathrm{a}$ & $0.43 \mathrm{~b}$ & $0.40 \mathrm{~b}$ & $1.0 \mathrm{a}$ & $94 \mathrm{a}$ & $95.0 \mathrm{a}$ \\
\hline
\end{tabular}

* Means within a column followed by the same letter not significantly different at $1 \%$ level. 
Height at the 1st 1982 cut and total green matter yield per $\mathrm{m}^{2}(1981+1982)$ are reported in table 5 . Seed producer plants were characterized by average heights close together and twice those of no seed producer plants $(62.64 \mathrm{~cm}$ vs $35.56 \mathrm{~cm}$ in mixture A, $65.05 \mathrm{~cm}$ vs $31.40 \mathrm{~cm}$ in B and $67.01 \mathrm{~cm} v s 31.19 \mathrm{~cm}$ in C). For what total green matter yield per $\mathrm{m}^{2}$ is concerned, seed producer plants yielded $65 \%, 76 \%$ and $73 \%$ of the total in mixtures $\mathrm{A}, \mathrm{B}$ and $\mathrm{C}$ respectively. These results confirm that, under dense stand conditions, plants superior in height, which is one of the most powerful characters governing competitive ability (ROTILI \& ZANNONE, 1974, 1975 ; YAMADA \& HORIUCHI, 1960) are the most productive both in forage and in seed.

\section{CONCLUSIONS}

The present research suggests the possibility of studing alfalfa populations under competitive conditions similar to those of a normal stand. Under these conditions, forage yield of $S_{1}$ plants is much lower than that of $F_{1}$ plants in a mixture, and this inbreeding effect tends to increase over time. As already shown in our preliminary results (VERONESI \& LORENZETTI, 1983), average $S_{1}$ green matter yield is confirmed to be not significantly affected by their percentage in the mixture. The constant low yield of inbred plants seems to be associated with their inbred condition rather than with the presence of a lower or higher number of high competitive phenotypes. On the contrary, $F_{1}$ plants tend to increase their average yield as the percentage of $S_{1}$ plants in the mixture increases, showing high competitive effects. As a consequence, no differences were observed in dry matter yield $/ \mathrm{m}^{2}$ among mixtures and, in accordance with the results of TYSDAL \& KIESSELBACH (1944) and PARRINI (1963), an increase or decrease of $S_{1}$ seed percentage in the initial seed lot would not seem very important with respect to productivity of an alfalfa stand both in the seeding and in the second year. Selective elimination of $S_{1}$ plants was very strong and, one year after seeding, only few $S_{1}$ plants survived, irrespective of their percentage in the initial seed lot.
TABLE 5

Height per plant at the first $1982 \mathrm{cut}(\mathrm{cm})$ and total green matter yield per $m^{2}(1981+1982)$ of non seed producer and seed producer plants, respectively.

Hauteur des plantes à la $1^{r e}$ coupe de 1982 (en $\mathrm{cm}$ ) et production totale de matière verte par $m^{2}(1981+1982)$ respectivement des plantes non productrices et des plantes productrices de semences.

\begin{tabular}{|c|c|c|c|}
\hline & \multirow{2}{*}{ Mixtures } & \multicolumn{2}{|c|}{ Characters } \\
\hline & & $\begin{array}{c}\text { Height } \\
(3 / 15 / 1982) \\
(\mathrm{cm})\end{array}$ & $\begin{array}{l}\text { Total green } \\
\text { matter yield } \\
\left(\mathrm{g} / \mathrm{m}^{2}\right)\end{array}$ \\
\hline \multirow{3}{*}{ A } & Non seed producers & 35.56 & 2091 \\
\hline & Seed producers & 62.64 & 3849 \\
\hline & Total & 48.19 & 5940 \\
\hline \multirow{3}{*}{$\mathrm{B}$} & Non seed producers & 31.40 & 1556 \\
\hline & Seed producers & 65.05 & 5074 \\
\hline & Total & 50.84 & 6630 \\
\hline \multirow{3}{*}{$\mathrm{C}$} & Non seed producers & 31.19 & 1666 \\
\hline & Seed producers & 67.01 & 4434 \\
\hline & Total & 50.89 & 6100 \\
\hline
\end{tabular}

Only $0 \%, 0.6 \%$ and $1 \%$ of the seed produced in the second year came from $S_{1}$ plants in $A, B$ and $C$ mixtures, respectively. Therefore, in alfalfa stands which have undergone competition, it seems likely that $S_{1}$ plants do not significantly contribute to seed yield. For this reason, it seems almost impossible that, in an alfalfa stands, plants derived from more than one cycle of selfing are present. The highest yielding phenotypes, which produced $60-70 \%$ of the total forage yield and $100 \%$ of the seed yield, were almost all $F_{1}$ plants coming from $15-20 \%$ of the seed sown and were characterized by an average height twice the others; this indicates that, as already shown by LORENZETTI (1981), in a leguminous forage species such as alfalfa forage yield selection is not incompatible with seed yield selection and can be done under dense stand conditions.

Reçu le 17 décembre 1983. Accepté le 5 juillet 1984.

\section{REFERENCES}

Bonciarelli F., 1960. Risultati di una prova di controllo di impollinazione su Medicago sativa L. Ric. Sci., 12, 1978-1989.

Brown B. A., Decker A. A., Sprague M. A., Mac Donald H. A., Teel M. R., 1960. Md Agric. Exp. Stn Northeast Reg. Publ. N. 41, Bull. A-108.

Busbice T. H., Hill Jr. R. R., Carnahan H. L., 1972. Genetics and breeding procedures. In C. H. Hanson: "Alfalfa Science and Technology ». Agronomy, 15, 283-318. Am. Soc. Agron., Madison, Wis.

Carnahan H. L., Paden R. N., 1967. Effects of vigor of $S_{1}$ lines and seeding rates on yield and final stand of an alfalfa two clone combination admixed with different percentages of $\mathrm{S}_{1}$ seed. Crop Sci., 7, 9-13.
Christie B. R., Keoghan J. M., 1979. The use of simulated swards in breeding alfalfa (Medicago sativa L.). Can. J. Plant Sci., 59, 701-706.

Demarly Y., Guy P., Chesneaux M. T., 1964. Analyses préliminaires de la compétition chez les luzernes. Ann. Amél. Plantes, 14, $131-155$.

Haussmann G., 1955. Densità di semina dei medicai in rapporto al substrato. Ann. Accad. Agric. Torino, 97, 1-18.

Kehr W. R., 1976. Cross-fertilization in seed production in relation to forage yield in alfalfa. Crop Sci., 16, 81-86.

Lesins K., 1961. Mode of fertilization in relation to breeding methods in alfalfa. Z. Pflanzenzüchtung, 43, 31-54. 
Lorenzetti F., 1978. Autofecondazione e fecondazione incrociata in erba medica. Sementi Elette, $X X I V$, 33-37.

Lorenzetti F., 1981. Relationships between dry matter and seed yield in leguminous forage plants. Proc. Eucarpia Fodder Crops Section Meet., Merelbeke, Belgium, 8-10 Sept. 1981, 153-162.

Lorenzetti F., Porceddu E., 1968. Honey-bees and production of polycrosssed lucerne seed. Z. Pflanzenzüchtung, 60, 156-164.

Lorenzetti F., Porceddu E., 1977. Aspetti genetici dell'attività sementiera. Riv. di Agron., XI, 3-32.

Panella A., 1960. Il diradamento dei medicai e il problema della resistenza. Prog. Agric., VI, N. 7.

Panella A., Lorenzetti F., 1966. Selfing and selection in alfalfa breeding programmes. Euphytica, 15, 248-257.

Panella A., Lorenzetti F., 1968. Choice of the basic plants for improved lucerne varieties. Genet. Agrar., XXIII, 324-333.

Parrini P., 1963. L'effetto della competizione tra le piante sulla espressione del vigore ibrido nell'erba medica. Ric. Sci. Anno 33, 4, 345-358.

Pearson L. C., Elling L. J., 1961. Predicting synthetic varietal performances in alfalfa from clonal cross data. Crop Sci., 1, 263-266.

Rotili P., 1979. Contribution à la mise au point d'une méthode de sélection de la luzerne prenant en compte les effects d'interférence entre les individus. 1. Etude expérimentale de la structure de la luzernière. Ann. Amél. Plantes, 29, 353-381.

Rotili P., Zannone L., 1974. General and specific combining ability in lucerne at different levels of inbreeding and performance of second generation synthetics measured in competitive conditions. Euphytica, 23, 569-577.
Rotili P., Zannone L., 1975. Principaux aspects d'une méthode de sélection de la luzerne basée sur des dispositifs qui utilisent la concurrence entre les plantes. Ann. Amél. Plantes, 25, 29-49.

Schaaf H. M., 1976. Space-planted and mass-seeded progeny test for seed yield and seed size in tetraploid crested wheatgrass. Crop Sci., 16, 607-610.

Tesar M. B., Jackobs J. A., 1972. Establishing the stand. In C. H. Hanson : «Alfalfa Science and Technology ». Agronomy, 15, 415435. Am. Soc. of Agron. Madison, Wis.

Tysdal H. M., Kiesselbach T. A., 1944. Hybrid alfalfa. J. Am. Soc. Agron., 36, 649-667.

Veronesi F., Lorenzetti F., 1982. Nuovi dati sulla quota di autofecondazione in erba medica. Riv. di Agron., XVI, 103-109.

Veronesi F., Lorenzetti F., 1983. Productivity and survival of alfalfa hybrid and inbred plants under competitive conditions. Crop Sci., 23, 557-580.

Veronesi F., Lorenzetti F., Porceddu E., 1982. Pollination and seed regeneration in lucerne. Proc. of the C.E.C./European Seminar on "Seed regeneration in cross-pollinated species", Nyborg, Denmark, 15-17 July 1981, 87-96.

Vivenza A., 1914. La vita del medicaio. Le St. Sper. Agr. It., XLVII, 97-118.

Yamada T., Horiuchi S., 1960. On the bias of quantitative characters and the change of their distribution in a population due to inter-plant competition. Proc. of the 8th Int. Grassl. Congr., Reading (England), 11-12 July 1960, 297-301. 